\title{
TERAPI OKUPASI MENYULAM UNTUK MENINGKATKAN KEMAMPUAN MOTORIK HALUS PADA SISWA TUNAGRAHITA RINGAN DI SLB YAPENAS YOGYAKARTA
}

\author{
Da'watul Islamiyah ${ }^{1}$, Rahma Widyana ${ }^{2}$ \\ ${ }^{12}$ Universitas Mercu Buana Yogyakarta \\ umifaqih4@yahoo.com
}

\begin{abstract}
Abstrak
Terapi okupasi menyulam adalah terapi yang melatih gerapak halus dari tangan dan merupakan suatu peluang memberikan suatu keaktifan kerja kepada siswa tunagrahita ringan. tujuan penelitian ini adalah untuk meningkatkan kemampuan motorik halus pada siswa tunangrahita ringan. Rancangan penelitian yang digunakan adalah single case eksperimen dengan melihat hasil pretest dan posttest subjek terapi melalui visual inspection dan uji parametrik paired sampel t-test untuk melihat apakah ada perbedaan sebelum dan sesudah pemberian terapi okupasi dilakukan. Hasil penelitian memperlihatkan bahwa terapi okupasi dapat meningkatkan kemampuan motorik hasil pada siswa tunagrahita ringan.
\end{abstract}

Kata kunci : Terapi okupasi menyulam, kemampuan motorik halus, tunagrahita ringan

\section{EMBROIDER OCCUPATIONAL THERAPY TO IMPROVE FINE MOTOR SKILL IN MILD MENTALLY RETARDED STUDENTS IN SLB YAPENAS YOGYAKARTA}

\author{
Da'watul Islamiyah', Rahma Widyana ${ }^{2}$ \\ ${ }^{12}$ Universitas Mercu Buana Yogyakarta \\ ²umifaqih4@yahoo.com
}

\begin{abstract}
Embroider occupational therapy is a therapy that trains the subtle movements of the hands and is an opportunity to provide work activeness to mild mentally retarded students. The purpose of this study is to increase fine motor skill in mild mentally retarded students. The research design used was a single case experiment by observing the result of pre-test and post-test of the therapy subject to find out whether there is a difference before and after the occupational therapy done. The result of this research shows that occupational therapy can improve fine motor skill in mild mentally retarded students.
\end{abstract}

Keywords: Embroider occupational therapy, fine motor skill, mild mental retardation

\section{PENDAHULUAN}

Kemampuan kognitif bagi setiap individu tidaklah sama satu sama lainnya, ada yang berinteligensi di atas rata-rata, normal hingga kemampuan di bawah rata-rata atau yang biasa disebut dengan retardasi mental atau tunagrahita. Tunagrahita adalah salah satu istilah yang biasa digunakan bagi penderita lemah mental atau disebut juga dengan cacat mental. Ciri anak tunagrahita yang menonjol adalah IQ (intelligence quotient) yang rendah jika dibandingkan dengan anak normal lainnya. Anak dengan tunagrahita kurang dapat membedakan mana yang baik dan yang buruk dikarenakan daya nalar yang dimiliki juga tergolong rendah. Anak dengan tunagrahita selain memiliki masalah dalam intelektualnya, anak tunagrahita juga bermasalah dengan 
perkembangan dan pertumbuhannya. Seperti dalam perkembangan motorik halus dan kasar, verbal, konsentrasi rendah, daya abstraksi rendah dan lain sebagainya. Oleh karena itu anak tunagrahita membutuhkan waktu lebih lama untuk memahami bahkan menirukan hal yang biasa dilakukan anak normal (Ashman dalam Mangunsong, 2009).

Istilah-istilah yang sering digunakan untuk mereka yang mengalami keterbelakangan mental atau tunagrahita antara lain feeble mindedness (lemah pikiran), mental subnormality, cacat mental, defisit mental, bodoh, dungu. Apabila dilihat dari asal katanya, tuna berarti merugi sedangkan grahita berarti pikiran. Tunagrahita merupakan kata lain dari retardasi mental (mental reterdation) yang berarti terbelakang secara mental (Ashman dalam Mangunsong, 2009).

Retardasi mental atau tunagrahita adalah keadaan seseorang dengan inteligensi yang kurang sejak masa perkembangan (sejak lahir atau sejak masa anak). Biasanya terdapat perkembangan mental yang kurang secara keseluruhan. Tetapi gejala utama yang muncul ialah inteligensi yang terbelakang. Retardasi mental juga disebut sebagai oligofrenia (oligo $=$ kurang atau sedikit dan fren $=$ jiwa) atau tuna mental (Maramis \& Maramis, 2004).

Menurut American Asociation on Mental Deficiency (AAMD) dari Grossman (dalam Mangunsong, 2009) mendefinisikan Tunagrahita sebagai suatu kelainan yang fungsi intelektual umumnya di bawah rata- rata, yaitu IQ 84 ke bawah. Biasanya anak-anak tunagrahita akan mengalami kesulitan dalam "Adaptive Behavior" atau penyesuaian perilaku.
Hal ini dimungkinkan anak tunagrahita tidak dapat mencapai kemandirian yang sesuai dengan ukuran (standard) kemandirian dan tanggung jawab sosial anak normal yang lainnya dan juga akan mengalami masalah dalam keterampilan akademik dan berkomunikasi dengan kelompok usia sebaya.

Selain kemampuan kognitif, perkembangan motorik penting untuk diasah. Hal tersebut juga berlaku bagi anak tunagrahita. Anak tunagrahita yang memiliki motorik halus yang rendah, biasanya cenderung kurang mampu melakukan kegiatan-kegiatan yang berkaitan dengan koordinasi antara mata dengan tangan, contohnya menulis, memegang, mengancing, melempar dan lain sebagainya.

Kemampuan motorik terbagi dua yaitu motorik kasar dan motorik halus. Motorik kasar adalah aktivitas dengan menggunakan otot-otot besar yang meliputi gerak dasar lokomotor, non lokomotor, dan manipulatif, sedangkan yang dimaksud dengan motorik halus adalah kemampuan anak untuk beraktivitas menggunakan otot-otot halus (otot kecil) seperti menulis, menggambar dan lain-lain (Samsudin, 2005).

Dari hasil observasi yang peneliti lakukan di SLB Yapenas, terdapat kelompok anak tunagrahita $(\mathrm{C})$ dengan jenis tunagrahita ringan, sedang dan berat. Ketiga jenis anak tunagrahita tersebut memiliki ciri masing-masing pada perkembangan kognitif, afektif maupun psikomotorik, tetapi hampir semua anak mengalami hambatan dalam perkembangan motoriknya. Misalnya siswa $G$ dengan latar belakang tunagrahita ringan, mengalami keterlambatan pada kemampuan motorik halus, 
siswa $\mathrm{G}$ terlihat kesulitan untuk tulis menulis di kertas, di papan tulis atau menggambar, pada saat guru memberikan keterampilan meronce manic siswa $G$ terlihat kesulitan, akan tetapi siswa G sudah mampu melakukan kegiatan pribadinya seperti mandi, memakai pakaian, makan hingga menyisir rambut meskipun dengan bimbingan orang tua.

Hasil observasi di atas selaras dengan hasil wawancara yang dilakukan dengan guruguru pengajar di SLB ini, menurut guru pengajar banyak siswa yang mengalami latar belakangan tunagrahita ringan mengalami keterlambatan pula pada aspek motoriknya, siswa masih terlihat kesulitan dalam hal memegang pensil, menulis di buku atau di papan tulis, siswa tunagrahita ringan terlihat kaku dalam mengerjakan aktivitas tersebut. Hal tersebut dikarenakan salah satu ciri dari anak tunagrahita adalah selain mengalami keterlambatan dalam aspek kognitif, siswa juga memiliki keterlambatan pada aspek motorik (Ashman dalam Mangunsong, 2009).

Pentingnya perkembangan motorik bagi anak tunagrahita adalah karena dengan perkembangan motorik yang baik, anak tunagrahita mampu melakukan kegiatankegiatan dasar dalam kehidupan sehari-hari seperti makan (memegang sendok, memegang gelas), mandi dengan tanpa bantuan (memegang gayung, menyikat gigi) memakai baju, sepatu hingga aktivitas yang berkaitan dengan proses pembelajaran di sekolah (menulis, menggambar). Perkembangan motorik dasar merupakan hal penting selama masa kanakkanak. Semua anak-anak, kecuali siswa yang mengalami keterbelakangan dalam pertumbuhan dan perkembangan, mampu mengembangkan dan mempelajari berbagai macam gerak. Gerakan-gerakan demikian merupakan pengulangan terus menerus dari kebiasaan dan menjadikannya dasar dari pengalaman lingkungan mereka (Mumpuniarti, 2000). Anak dengan tunagrahita diharapkan mampu mengasah kemampuan motorik halusnya agar tidak mengalami kesulitan berkaitan dengan penggunaan motorik halus seperti memegang sendok, memakai baju, kancing baju, hingga yang berkaitan dengan proses belajar bengajar seperti menulis dan menggambar.

Dengan demikian perlu adanya terapi khusus yang dapat meningkatkan kemampuan motorik siswa tersebut, salah satu terapi yang dapat meningkatkan kemampuan motoriknya adalah terapi okupasi. Terapi okupasi juga merupakan terapi yang bisa digunakan untuk meningkatkan kemampuan motorik pada siswa berkebutuhan khusus, terapi okupasi juga bertujuan untuk membantu seseorang agar dapat melakukan kegiatan keseharian, aktivitas produktivitas dan pemanfaatan waktu luang.

Menurut Soebadi (dalam Nurlina, 2008) terapi okupasi adalah terapi yang melatih gerakan halus dari tangan dan integrasi dari gerakan dasar yang sudah di kuasai melalui permainan dan alat-alat yang sesuai. Tarmansyah (dalam Nurlina, 2008) menyatakan bahwa terapi okupasi memberikan peluang dan kesempatan bagi anak-anak untuk mengembangkan bakat, daya, inisiatif, daya kreativitas, kemampuan bercita-cita, berkarsa dan berkarya. 
Menurut Smart (2012) tujuan proses pembelajaran pada terapi ini adalah untuk menumbuh kembangkan atau meningkatkan kompetensi dan koordinasi, kekuatan dan kecepatan, ketangkasan, keseimbangan, masalah gerak dan sikap anak-anak penyandang tunagrahita tersebut. Koordinasi mengacu pada kemampuan manipulasi anggota tubuh mereka terhadap objek tertentu secara lancar. Kekuatan berkenaan dengan kapasitas mengeluarkan tenaga, seperti kemampuan untuk memegang suatu benda, sedangkan ketangkasan berhubungan dengan koordinasi, seperti kemampuan untuk memegang benda atau menangkap objek, kesadaraan berkenaan dengan adanya gerak dan koordinasi merupakan unsur yang menjadi perhatian dalam pengembangan psikomotorik bagi anak-anak yang memiliki kebutuhan khusus.

Pada penelitian Nurlina (2008), terapi okupasi dipraktekkan melalui kegiatan keterampilan pita rambut. Keterampilan pita rambut ini dapat membantu anak memaksimalkan fungsi gerak tangan dan daya konsentrasinya yang mana gerak yang digunakan adalah sendi dan otot-otot kecil (Nurlina, 2008). Dalam hal ini meronce, menenun, menyulam hingga bermain lempar bola juga memiliki fungsi yang sama yaitu memaksimalkan fungsi gerak tangan dan daya konsentrasi subjek sehingga subjek dapat memainkan keterampilan tersebut dengan baik dan teliti. Berdasarkan pada analisis data di lapangan pada penelitian di Putra Jaya Malang, dapat disimpulkan bahwa penerapan terapi okupasi melalui keterampilan pita rambut pada anak tunagrahita di sekolah ini lebih memfokuskan pada prosesnya, bukan pada hasilnya, karena dalam kegiatan ini yang digunakan adalah gerak motorik halus dan kasar serta pemusatan konsentrasi. Diberikannya terapi okupasi ini untuk meningkatkan kemampuan motorik halus supaya dapat melatih kemampuan siswa dalam berkonsentrasi dan melatih gerakan otot-otot tangan sehingga otototot tersebut lebih lentur dan nantinya diharapkan siswa mampu melakukan pekerjaan yang lebih memaksimalkan fungsi gerak dan daya konsentrsi seperti menjahit, menyulam dan sebagainya.

Pada penelitian ini, terapi okupasi yang diberikan adalah terapi okupasi menyulam. Terapi okupasi menyulam merupakan stimulus yang diberikan oleh guru atau terapis guna meningkatkan kemampuan motorik halus pada siswa tunagrahita ringan. Diberikannya terapi okupasi menyulam pada siswa, diharapkan siswa yang mengalami tunagrahita ringan nantinya jika telah selesai masa pendidikannya di SLB dapat memiliki keterampilan yang dapat digunakan untuk menunjang kehidupan seharihari. Diberikannya keterampilan tersebut, diharapkan siswa mampu bersosialisasi dengan lingkungannya dan mampu menggunakan keahliannya sebagai sarana untuk mencukupi kebutuhan sehari-hari, karena pada dasarnya siswa dengan tunagrahita ringan adalah siswa yang mampu latih dan mampu untuk dididik selayaknya anak normal meskipun membutuhkan waktu yang relatif lebih lama, jadi keterampilan tersebut nantinya akan diajarkan kepada siswa dengan harapan siswa dapat menggunakan keterampilan menyulam sebagai bekal dikemudian hari. 
Menurut Suriptini (2012), keterampilan menyulam dengan tangan bagi anak tunagrahita merupakan suatu metode yang fungsinya merupakan suatu alat atau sarana untuk mencapai suatu tujuan. Jadi dengan terapi okupasi menyulam ini diharapkan siswa tunagrahita dapat memperoleh suatu manfaat yang telah menjadi tujuan bersama yaitu meningkatnya kemampuan motorik. Karena dalam terapi okupasi menyulam ini, siswa dilatih untuk mengasah koordinasi antara tangan dengan mata dan melatih pergelangan tangan saat siswa melakukan kegiatan menyulam. Pada terapi okupasi menyulam ini, mengacu pada ciri-ciri kemampuan motorik halus menurut Alimin (2012), siswa diharapkan mampu untuk melilit (throwing), menusuk atau memasukkan (striking), serta menarik (catching). Berdasarkan hasil wawancara dengan terapis, pada terapi okupasi menyulam ini, salah satu aspek prilaku yang diberikan kepada siswa tidak menggunakan aspek melilit (throwing) karena pada menyulam dasar tidak harus melilit (throwing), akan tetapi menggunakan aspek memasang (installing).

Selain terapi okupasi di atas, para ahli banyak melakukan penelitian tentang beberapa terapi yang dapat meningkatkan kemampuan motorik anak tunagrahita seperti penerapan terapi bermain bola untuk meningkatkan kemampuan motorik kasar pada anak tunagrahita ringan. Penelitian Haryani dan Dewi (2013) merupakan penelitian eksperimen yang nantinya siswa tunagrahita diberi perlakuan terapi bermain bola untuk meningkatkan kemampuan motorik. Selain itu, fisioterapi juga merupakan salah satu jenis layanan terapi yang bisa meningkatkan kemampuan motorik, hal ini karena fisioterapi menitikberatkan untuk menstabilkan atau memperbaiki fungsi alat gerak atau fungsi tubuh yang terganggu. Layanan fisioterapi ini umumnya bagi anak dengan keterbatasan fisik, tunadaksa, cerebral palsy dan anak-anak yang mengalami keterlambatan atau gangguan pada kemampuan motorik, pasca stroke yang memerlukan pemulihan kondisi fisiknya serta trauma lain yang menyebabkan penampilan fisik terganggu.

Selanjutnya pada penelitian ini, peneliti akan memberikan terapi okupasi menyulam untuk meningkatkan kemampuan motorik halus pada siswa tunagrahita ringan karena terapi okupasi merupakan terapi yang memberikan suatu keaktifan kerja berupa kesibukan yang disesuaikan dengan kemampuan individu. Diharapkan dengan pemberian keterampilan ini dapat mengurangi penderitaan yang dialami indivudu secara bertahap dan nantinya pada jangka panjang diharapkan keterampilan ini menjadi keterampilan yang dapat menopang kehidupan siswa setelah lulus dari sekolah.

Intervensi yang diberikan adalah terapi okupasi menyulam pada siswa tunagrahita ringan pada penelitian ini, diharapkan dapat meningkatkan kemampuan motorik halus siswa karena di dalam terapi okupasi menyulam siswa diberikan kegiatan yang membutuhkan kecepatan dan ketepatan pergelangan serta jarijari dalam menggunakan alat serta koordinasi antara mata dengan tangan. Nantinya setelah pemberian terapi okupasi menyulam secara berulang-ulang, diharapkan terapi okupasi menyulam ini menjadi suatu keahlian siswa sehingga apabila siswa telah lulus dari SLB, 
siswa memiliki keahlian yang bisa digunakan untuk pemenuhan dalam kehidupan sehari-hari.

\section{METODE}

Subjek dalam penelitian ini adalah siswa SLB Yapenas kategori C yaitu siswa tunagrahita ringan. Pemilihan subjek ini didasarkan pada siswa yang mengalami tunagrahita di SLB ini. Siswa yang nantinya akan diberi terapi okupasi sebanyak 3 orang siswa. Adapun kriteria subjek dalam penelitian ini adalah siswa tunagrahita ringan, memiliki kemampuan motorik yang rendah, memiliki daya abstraksi rendah, memiliki komunikasi verbal yang minim.

Metode pengukuran dalam penelitian ini dilakukan dengan menggunakan observasi menggunakan lembar rating kemampuan motorik yang mengacu pada rating scale dan metode observasi sistematik (Hadi, 2004). Ditinjau dari keterlibatan pelaku observasi dalam mendapatkan informasi, observasi dalam penelitian ini merupakan observasi partisipan dan non partisipan (Arikunto, 2007). Alat ukur yang digunakan dalam penelitian ini meliputi skala rating kemampuan motorik berdasarkan hasil observasi. Skala rating adalah ukuran subjektif yang dibuat berskala (Behavioral chek list). Format disusun berisi aitem-aitem tentang kejadian atau tingkah laku yang digambarkan akan terjadi. Behavioral chek list ini bertujuan untuk menggukur perkembangan motorik halus yang terjadi pada subjek sebelum dan setelah pemberian terapi okupasi menyulam. Observer atau pengamat melakukan penilaian terhadap hasil amatannya kepada subjek yang diamati, dalam hal ini yang diamati adalah kemampuan motorik halus pada pada saat menyulam, hasil penelitian itu diterapkan ke dalam suatu skala bertingkat (Arikunto, 1998). Aitem-aitem kemampuan motorik disusun berdasarkan aspek kemampuan motorik halus menurut Alimin (2012) dan berdasarkan hasil wawancara yang dilakukan dengan terapis terapi okupasi menyulam yaitu: memasang (installing), menusuk atau memasukkan (striking), menarik (catching), dengan kriteria penilaian terapi okupasi menyulam sebagai berikut:

a Simbol angka 3 jika siswa dapat melakukan tanpa bantuan

b Simbol angka 2 jika siswa dapat melakukan dengan sedikit bantuan

c Simbol angka 1 jika siswa dapat melakukan dengan bantuan.

Pemberian skor per-aspek harus dengan melihat kondisi dilapangan, bukan membayangkan melihat yang sudah terjadi. Kolom keterangan pada tabel ciri-ciri kemampuan motorik halus digunakan untuk menuliskan keterangan observer untuk melengkapi hasil penilaian yang ditemukan pada saat mengobservasi kegiatan subjek.

Validitas alat ukur penelitian ini diperoleh berdasarkan validasi isi. Pada awalnya uji validasi ini terhadap indikatorindikator skala dilakukan oleh seorang profesional dalam proses professional judgement. Profesional yang dilibatkan adalah guru keterampilan senior yang telah berpengalaman dibidang keterampilan menyulam. Langkah selanjutnya adalah dengan menguji reliabilitas hasil rating penelitian yang dilakukan oleh rater yang dibandingkan dengan 
menggunakan teknik uji korelasi Speamen. Penelitian ini menggunakan tiga orang rater untuk meminimalkan pengaruh subjektivitas dalam memberikan skor. Di bawah ini data mentah uji reliabilitas antar rater pada ketiga subjek penelitian terapi okupasi menyulam.

Koefisien korelasi antara rater 1, 2 dan 3 sebesar 1.000 yang berarti korelasi antara ketiga rater tersebut dapat dikatakan memiliki keterkaitan yang sangat tinggi antara yang satu dengan yang lainnya. Jadi, penilaian rater 1, penilaian rater 2 dan penilaian rater 3 berkorelasi satu sama lain atau bersifat identik.

Pedoman wawancara dengan tema kemampuan motorik pada siswa tunagrahita yang akan dikenakan pada orangtua dan guru pengajar di sekolah. Tujuan wawancara adalah untuk menggali informasi lebih dalam tentang pribadi subjek serta kegiatan sehari-hari yang berkaitan dengan subjek di sekolah dan di rumah. Informasi yang didapat selanjutnya dirangkum dalam aspek kemampuan motorik halus yaitu koordinasi antara mata dengan tangan, kecepatan dan ketepatan anak dalam melakukan suatu kegiatan (Mumpuniarti, 2000) dan ciri-ciri kemampuan motorik halus menurut Alimin (2012) yaitu: melilit, menusukkan atau memasukkan serta menarik.

\section{HASIL DAN PEMBAHASAN}

Berdasarkan hasil analisis visual inspection dan dikaitkan dengan hasil analisis kuantitatif dengan menggunakan uji parametrik paired sample t-test menunjukkan koefisien korelasi sebesar 0.1000 dengan taraf $\mathrm{Sig}=$ 0.002 ( $\mathrm{p}<0.005)$, hal ini menunjukkan ada perbedaan sebelum dan sesudah terapi okupasi menyulam diberikan pada siswa tunagrahita ringan. Dengan melihat hasil kedua analisis tersebut sebelum terapi diberikan dan setelah terapi diberikan dapat terlihat dari kenaikan skor kemampuan motorik halus setelah terapi okupasi menyulam diberikan.

Hasil penelitian ini mendukung penelitian yang dilakukan oleh Nurlina (2008) yaitu terapi okupasi yang dipraktekkan melalui kegiatan keterampilan pita rambut. Keterampilan pita rambut ini dapat membantu anak memaksimalkan fungsi gerak tangan dan daya konsentrasinya yang mana gerak yang digunakan adalah sendi dan otot-otot kecil (Nurlina, 2008). Dalam hal ini menyulam mempunyai fungsi yang sama yaitu memaksimalkan fungsi gerak tangan dan daya konsentrasi subjek sehingga subjek dapat memainkan keterampilan tersebut dengan baik dan teliti.

Pada awal proses terapi okupasi semua peserta terapi membutuhkan bantuan terapis dalam melakukannya karena tiap subjek belum mampu melakukannya sendiri, misalnya pada saat menjiplak pola, subjek kurang mampu menjiplak dengan rapi dan cenderung bergeser, akan tetapi terapis mencontohkan dan meminta subjek melanjutkan dengan beberapa kali dikontrol oleh terapi, dikhawatirkan jiplakannya tidak terlihat sehingga dapat menyulitkan ketika menyulam. Proses-proses tersebut dilakukan pada setiap kali pertemuan kecuali menjiplak dilakukan tiga kali selama terapi berlangsung, tetapi proses lainnya seperti memasang pemindangan, memasukkan benang ke dalam jarum dilakukan setiap hari dengan intruksi terapis pada awal dimulainya 
terapi, hal tersebut bertujuan untuk mengingatkan kembali pada peserta terapi okupasi proses yang dilakukan pada hari kemarin. Awalnya peserta terapi terlihat kesulitan melakukannya, terlebih pada saat mengencangkan pemindangan, memasukkan benang ke dalam jarum, tetapi karena dilakukan berulang-ulang terjadi perubahan pada peserta terapi, mulai dari melakukan dengan bantuan, sedikit bantuan hingga tanpa bantuan.

Pada diagram 1 yaitu subjek pertama (F) terjadi perubahan dari skor 9 sebelum terapi diberikan dan meningkat menjadi skor 15 setelah diberikan terapi okupasi menyulam. Kemampuan motorik subjek bisa dikatakan cukup baik pada saat terapi okupasi, kemampuan motorik subjek bisa dibilang hampir seperti anak normal meskipun lebih lambat, subjek terlihat lebih menonjol dari yang lainnya ketika proses terapi okupasi, hal tersebut dimungkinkan karena sifat pendiam dan konsentrasi subjek mendengarkan dan mengerjakan intruksi yang diberikan oleh terapis. Subjek juga merupakan peserta yang sudah mampu memadupadankan warna, hasil sulaman subjek terlihat bagus dengan kombinasi warna yang subjek pilih. Kondisi subjek tersebut bisa dijadikan acuan supaya subjek lebih diasah lagi bidang keterampilannya dengan harapan nantinya subjek memiliki keterampilan yang bisa dijadikan sumber mata pencaharian dikehidupan mendatang.

Pada diagram 2 yaitu pada subjek kedua (N) terjadi peningkatan sebelum terapi diberikan yaitu dari skor 6 meningkat menjadi
13. Pada saat proses menyulam, subjek banyak mengobrol dengan peserta terapi okupasi (R), subjek sering diingatkan oleh terapis agar lebih konsentrasi karena ketidakkonsentrasian tersebut berakibat pada sulaman subjek menjadi kurang rapi, benang sering kusut sehingga subjek menjadi tertinggal dari subjek lainnya. Terapis sering memotivasi subjek dan peserta terapi lainnya supaya lebih konsentrasi dan bersemagat pada saat menyulam. Bahkan terapis sering memberikan pujian jika subjek mampu melakukan satu hal dengan sedikit atau tanpa bantuan terapis.

Kemampuan motorik subjek cukup baik pada saat terapi okupasi, hal tersebut dilihat dari kemapuan subjek memakai alat terapi okupasi, meskipun tidak sebaik anak normal. Subjek merupakan siswa yang belum dapat memadupadankan warna, warna benang yang subjek pilih sesui dengan keinginan subjek, padahal terapis sudah mengarahkan warna kepada subjek agar sulaman taplak meja menjadi bagus, akan tetapi subjek tidak mau mengikuti arahan terapis, tetapi subjek mampu mengikuti proses terapi okupasi hingga selesai setiap harinya.

Kemampuan motorik halus subjek mengalami peningkatan dilihat dari grafik skor sebelum dan setelah pemberian terapi okupasi, subjek mengalami kenaikan skor yang cukup baik. Hal tersebut bisa dijadikan acuan pihak sekolah dan keluarga agar lebih mengasah keterampilan subjek, diharapkan keterampilan tersebut dapat digunakan saat subjek telah terjun dimasyarakat.

Kemudian pada diagram 3 yaitu pada subjek ketiga $(\mathrm{R})$ terjadi peningkatan sebelum 
diberikan terapi okupasi menyulam dari skor 6 menjadi skor 13. Pada saat terapis menjelaskan langkah-langkah yang akan dilakukan pada terapi okupasi menyulam, subjek mendengarkan terapis dengan baik, akan tetapi pada proses menyulam, subjek sering tidak focus dan kurang konsentrasi, subjek menjadi patner mengobrol subjek $\mathrm{N}$, mereka mengobrol banyak hal mulai dari artis idola hingga acara tv, subjek $\mathrm{N}$ dan $\mathrm{R}$ mengobrol sambil menyulam sehingga hasil sulaman menjadi kurang rapi, benang subjek $\mathrm{R}$ sering kusut (bundet) karena subjek kurang memperhitungkan saat menarik jarum dan benang, jika demikian subjek sering meminta tolong terapis untuk memperbaikinya. Beberapa kali terapis meminta subjek mencobanya sendiri. Terapis sering mengingatkan dan memotivasi subjek supaya lebih mengurangi obrolan agar mendapatkan hasil sulaman yang baik.

Meskipun subjek banyak mengobrol dan kurang fokus, secara kasat mata, dapat dilihat kemajuan subjek dalam terapi okupasi ini. Awalnya subjek kurang mampu menyematkan benang ke dalam jarum, memasang pemindangan, mengunci pemindangan hingga proses menyulam, akan tetapi akhirnya subjek berhasil tanpa bantuan terapis. Secara keseluruhan terapi okupasi menyulam yang diberikan kepada siswa tunagrahita ringan dapat dikatakan berjalan dengan lancar dan mengalami perubahan dari sebelum dan setelah pemberian terapi okupasi menyulam.

Terapi okupasi menyulam ini bertujuan untuk melatih gerak motorik halus subjek melalui persendian, koordinasi antara mata dengan tangan. Menurut Soebadi (dalam Nurlina, 2008) terapi okupasi adalah terapi yang melatih gerakan halus dari tangan dan integrasi dari gerakan dasar yang sudah di kuasai melalui permainan dan alat-alat yang sesuai, selanjtnya menurut Smart (2012) tujuan proses pembelajaran pada terapi ini adalah untuk menumbuh kembangkan atau meningkatkan kompetensi dan koordinasi, kekuatan dan kecepatan, ketangkasan, keseimbangan, masalah gerak dan sikap anakanak penyandang tunagrahita tersebut.

Pada terapi okupasi menyulam, siswa diajarkan untuk melatih kemampuan motorik halusnya melalui kegiatan menyulam, dalam kegiatan menyulam tersebut siswa diminta untuk memasukkan jarum ke dalam benang, menjiplak motif, memasang pemindangan hingga menyulam kain yang sudah dijiplak. Aktivitas tersebut membutuhkan konsentrasi dan kelenturan lengan serta koordinasi yang baik antara keduanya. Apabila hal tersebut diulang berkali-kali, pada akhirnya terapi okupasi tersebut dapat meningkatkan kemampuan motorik halus siswa dan nantinya diharapkan terapi okupasi menyulam ini menjadi keterampilan siswa sehingga apabila nantinya siswa telah lulus dari SLB, siswa dapat mengembangkan kemampuan menyulamnya menjadi suatu keahlian yang dapat menopang kehidupan siswa di masa mendatang.

Secara umum sasaran terapi okupasi menyulam adalah keadaan seseorang yang mengalami suatu gangguan fisik, mental pemulihan, pengembangan intelektual, emosi dan sosial. Dalam hal ini yang menjadi fokus 
utama peneliti adalah untuk melatih kemampuan motorik halus siswa tunagrahita ringan, diharapkan siswa mampu melakukan aktivitas kemampuan motorik halus yang berkaitan dengan kehidupan sehari-hari secara mandiri seperti, memegang sendok, memegang gayung, menyikat gigi, memasang kancing baju hingga yang berkaitan dengan akademik seperti menulis dan menggambar.

Berdasarkan uraian pembahasan di atas dapat disimpulkan bahwa pemberian terapi okupasi melalui keterampilan menyulam pada siswa tunagrahita ringan ini mengalami peningkatan yang baik karena diberikan secara berulang-ulang dan diharapkan siswa tetap berlatih agar motorik halus semakin meningkat serta siswa dapat mengembangkan kreativitasnya dalam hal keterampilan. Hasil penelitian ini menunjukkan bahwa terapi okupasi menyulam berjalan lancar dan menunjukkan perkembangan yang baik, akan tetapi siswa harus banyak berlatih berulangulang agar penguasaan materi dan prakteknya semakin baik, di mana terapi okupasi menyulam ini merupakan pemberian kesibukan yang melatih motorik halus atau mengurangi terjadinya kekakuan melalui koordinasi antara mata dengan tangan, selain itu juga dapat melatih konsentrasi, daya tahan dan perhatian terhadap sesuatu.

\section{KESIMPULAN}

Berdasarkan hasil dan pembahasa dapat disimpulkan bahwa:

1. Terapi okupasi menyulam dapat meningkatkan kemampuan motorik halus siswa tunagrahita ringan. Hal tersebut dapat dilihat dari gambar dari skor kemampuan motorik halus subjek sebelum dan setelah pemberian terapi okupasi.

2. Pemberian terapi okupasi menyulam.

3. Terapi okupasi menyulam dapat meningkatkan kemampuan motorik halus siswa tunagrahita ringan, dilihat dari hasil pretest dan postest pada uji parametrik paired sample t-test dengan koefisien korelasi sebesar 0.1000 dengan taraf Sig $=$ $0.002(\mathrm{p}<0.005)$, berarti ada perbedaan sebelum dan sesudah terapi okupasi menyulam diberikan.

\section{Saran}

Hasil penelitian menunjukkan bahwa efek terapi okupasi dapat meningkatkan kemampuan motorik halus pada siswa tunagrahita ringan, selain itu terapi okupasi menyulam ini juga mengajarkan keterampilan berupa keatifan kerja pada siswa tunagrahita ringan berupa keterampilan menyulam, akan tetapi perlu adanya latihan terus menerus untuk mengasah kemampuan siswa yang nantinya diharapkan menyulam ini menjadi suatu kreativitas siswa yang bisa dikembangkan ketika siswa telah lulus dari SLB ini.

Selain itu, perlu adanya dukungan dari pihak keluarga untuk selalu berkomunikasi secara aktif dengan pihak sekolah dengan tidak hanya menyerahkan pendidikan kepada pihak sekolah semata, disarankan pihak keluarga juga mendukung dan mengajarkan hal yang serupa yang diajarkan di sekolah.

Untuk peneliti selanjutnya disarankan pada saat proses terapi okupasi menyulam, diberikan waktu istirahat selama beberapa menit 
supaya subjek tidak merasa kelelahan pada proses terapi berlangsung.

\section{DAFTAR PUSTAKA}

Anggun. B. (2012). Jenis Sulaman. http:// bordiranggunkediri.wordpress.com/2012/ 03/. Diunduh pada tanggal 7 September 2013.

Arikunto. (2007). Prosedur Penelitian. Jakarta: Rineka Cipta

Astati. (1995). Terapi Okupasi, Bermain, dan Musik Untuk Anak Tunagrahita. Departemen Pendidikan Dan Kebudayaan Direktorat Jenderal Pendidikan Tinggi. Proyek Pendidikan Tenaga Guru

Anita. Y. (2009). Anak Tunagrahita. Diunduh pada tanggal 14 Mei 2013. https://sites.google.com/site/myarticle $1 / \mathrm{m}$ yarticle2/orthopedagogik/anaktunagrahita

Alimin. Z. (2012). Hambatan Belajar Dan Perkembangan Anak Dengan Gangguan Motorik (Modul 3). Bandung: Universitas Pendidikan Indonesia

Delaney. M.S. (2010). 101 Permainan \& Aktivitas Untuk Anak-anak Penderita Autisme, Asperger \& Gangguan Pemrosesan Sensorik. Yogyakarta: ANDI

DSM IV-TR. Kriteria Diasgnostik. Untuk Kalangan Sendiri.

Fazriyanti. W. (2012). Menyulam Life Skill Untuk Perempuan Mandiri. http://female.kompas.com/read/2012/04/1 0/. Diunduh pada tanggal 7 september 2013

Gustiana. A. D. (2011). Pengaruh Permainan Modifikasi Terhadap Kemampuan Motorik Kasar dan Kognitif Anak Usia Dini. (Studi kuasi eksperimen pada kelompok B TK Kartika dan TK Lab. UPI). Edisi khusus No. 2. ISSN 1412$565 X$.

Gusril. Dkk. (2006). Model Pengembangan Motorik Siswa Sekolah Dasar. Jurnal Pembelajaran. Diterbitkan Universitas Negeri Padang, 29(2)
Haryani. P., \& Dewi. K. (2013). Efektivitas Penerapan Terapi Bermain Bola Untuk Meningkatkan Kemampuan Motorik Kasar Pada Tunagrahita Ringan Kelas 1 SMPLB. Jurnal Penelitian Psikologi, 1(2).

Hurlock. (1978). Child Development. Sixth Edition. New York: Mc. Graw Hill, Inc.

Kartono. K. (1995). Psikologi Anak (Psikologi Perkembangan). Bandung: CV. Mandar Maju

Lubis. L., \& Pieter. Z. (2010). Pengantar Psikologi dalam Keperawatan. Jakarta: Kencana Pranada Media Group

Maramis. F. (2005). Ilmu Kedokteran Jiwa. Surabaya: Universitas Airlangga

Mangungsong. F. (2009).Psikologi dan Pendidikan Anak Berkebutuhan Khusus. Depok: Lembaga Pengembangan Sarana Pengukuran dan Pendidikan Psikologi UI.

Mumpuniarti (2000). Penanganan Anak Tunagrahita. Yogyakarta: Pendidikan Luar Biasa Universitas Negeri Yogyakarta

Nurlina. (2008). Terapi Okupasi untuk Keterampilan Pita Rambut Pada Anak Tunagrahita. Jurnal Pendidikan Luar Biasa, 4(1).

Riskasari. W. Dkk. (2011). Motorik Halus Pada Anak Usia Prasekolah Ditinjau Dari Bender Gestalt. Insan, 13(03),

Samsudin. (2005). Pengembangan Motorik di Taman Kanak-kanak. Jakarta: Fakultas Ilmu Keolahragaan Universitas Negeri Jakarta.

Safaria. T., \& Saputra. E. (2009). Managemen Emosi (Sebuah Panduan Cerdas Bagaimana Mengelola Emosi Positif Dalam Hidup Anda). Jakarta: Bumi Aksara

Soetjiningsih. (1994). Tumbuh Kembang Anak. Universitas Airlangga Surabaya: Surabaya 
Sukinah. (2012). Terapi Okupasi. Pendidikan Luar Biasa FIP UNY. Power Point Bahan Ajar

Suriptini (2012). Pelaksanaan Pembelajaran Keterampilan Menyulam Pada Anak Tunagrahita Ringan Kelas VIII SMPLB di SLB PGRI Minggir Sleman Yogyakarta. Skripsi. Fakultas Ilmu Pendidikan Universitas Negeri Yogyakarta. Tidak diterbitkan

Suniati, L. Yulianto, A. (2009). Psikologi Eksperimen. Jakarta: Indeks

Wati. I. D. (2008). Kemampuan Motorik Kasar Siswa Sekolah Dasar Penderita Obesitas di Kota Yogyakarta. Tesis. Ilmu Kesehatan Masyarakat. Pascasarjana Fakultas Kedokteran Universitas Gadjah Mada Yogyakarta. Tidak diterbitkan

Widayanti. G. (2011). Terapi Perilaku ABA (Applied Behavior Teraphy). Fak. Psikologi Univ. Diponegoro. Power Point

Zechmeister. J. dkk. (2007). Metodologi Penelitian Psikologi. Yogyakarta: Pustaka Pelajar 